\title{
SZALAGCSISZOLÓ TERVEZÉSE
}

\author{
Nádasi Máté \\ hallgató, Miskolci Egyetem \\ Gép- és Terméktervezési Intézet \\ 3515 Miskolc, Miskolc-Egyetemváros, e-mail: mate.nadasi@gmail.com \\ Takács Ágnes \\ egyetemi docens, Miskolci Egyetem \\ Gép- és Terméktervezési Intézet \\ 3515 Miskolc, Miskolc-Egyetemváros, e-mail: takacs.agnes@uni-miskolc.hu
}

\begin{abstract}
Absztrakt:
Az ipar nagy részén használják a csiszolást, mint megmunkálási müveletet. A csiszolószalagok cseréjével egy csiszológépen sokféle anyagminöséget meg lehet munkálni és sokféle felületi minöséget elö lehet vele állitani. Egy csiszológép egyaránt használható az asztalos munkákhoz, de a fémek megmunkálására is alkalmas. A cél egy olyan csiszológép tervezése, melyet az ipar adott területein könnyen, egyszerüen és biztonságosan tudnak használni és a későbbiekben, kisebb fejlesztésekkel többfunkciós géppé tehetö. A cikk ezen szalagcsiszoló tervezésének néhány kérdését foglalja össze.
\end{abstract}

Kulcsszavak: szalagcsiszoló, csiszolás, tervezés, VEM

\begin{abstract}
:
In many fields of the industry specialists use grinding as a working operation. By replacing the abrasive belts, a variety of material qualities can be manufactured on a grinding machine and a variety of surface qualities can be produced. A grinding machine can be used for carpentry work, but it is also suitable for machining metals. The aim is to design a belt grinder that can be used easily, simply and safely in specific areas of the industry and later with minor improvements it can be transformed to a multifunctional machine. This paper summarizes some of the questions about designing this belt grinder.
\end{abstract}

Keywords: belt grinder, grinding, design, FEM

\section{Bevezetés}

A fémipari és asztalosipari cégeknek általában nagy gépparkra van szükségük munkájuk elvégzéséhez. Ezen cégek nagy figyelmet fordítanak gépeik minőségére és magas fokú megbízhatóságára. A szalagcsiszoló egy olyan eszköz, amely mindkét iparterületen elengedhetetlen, ha precíz és gyors munkavégzésre van szükség. Jelenleg a piacon sokféle gép kapható a hobbi kategóriától a profi minőségig. A hobbi kategória olcsó, de pontatlan, iparszerü használatra alkalmatlan. Az ipari kategória már strapabíró, megbízható változat, az ára viszont magas. Kisebb cégek nem biztos, hogy megengedhetik maguknak. A két gépváltozat között nagy szakadék van mind árkategóriában, mind minőségben.

A koncepcióváltozatok a saját ötletek, valamint a www.espacenet.com és a www.google.hu/patents oldalakon végzett szabadalomkutatás, továbbá piackutatás során feltárt megoldások alapján kerültek 
megfogalmazásra. A kutatások azt mutatták, hogy kereskedelmi forgalomban többféle árkategóriában léteznek szalagcsiszoló gépek. Az ár a gépek nagy részénél tükrözi a minőséget is. Ezeket két nagy kategóriába sorolhatjuk:

- hobby/barkács célra kifejlesztett gépek,

- ipari célra kifejlesztett gépek.

A koncepcionális tervezés során számos lehetséges megoldásváltozat közül végül három megoldásváltozat került összehasonlításra Copeland módszer segítségével. [7, 8] Az értékelés segítségével kiválasztott változat révén egy biztonságos, egyszerúen üzemeltethető és karbantartható szalagcsiszoló gép valósítható meg. Az elözetes tervek alapján elkészült ennek a változatnak a 3D-s CAD modellje, amelyet az 1. ábra szemléltet. A tervezés további lépéseiben mérnöki számítások és VEM analízis elvégzésére került sor.

\section{Gép leírása}

$\mathrm{Az}$ 1. ábra a tervezés során elkészült négygörgős elrendezésủ gép CAD modelljét szemlélteti. A szalagfejen két fordító görgö, a motoron egy meghajtó- és a gép vázán egy feszítő- tájoló görgö található. A gép $100 \times 2000 \mathrm{~mm}$-es csiszolószalaghoz lett tervezve. A szalag sebessége fokozatmentesen állítható, $23 \mathrm{~m} / \mathrm{s} \div 35 \mathrm{~m} / \mathrm{s}$ tartományon. Az élettartam meghosszabbítása érdekében lassú indítású. A csiszolási müvelet a gép elején elhelyezett tárgyasztalon végezhető.

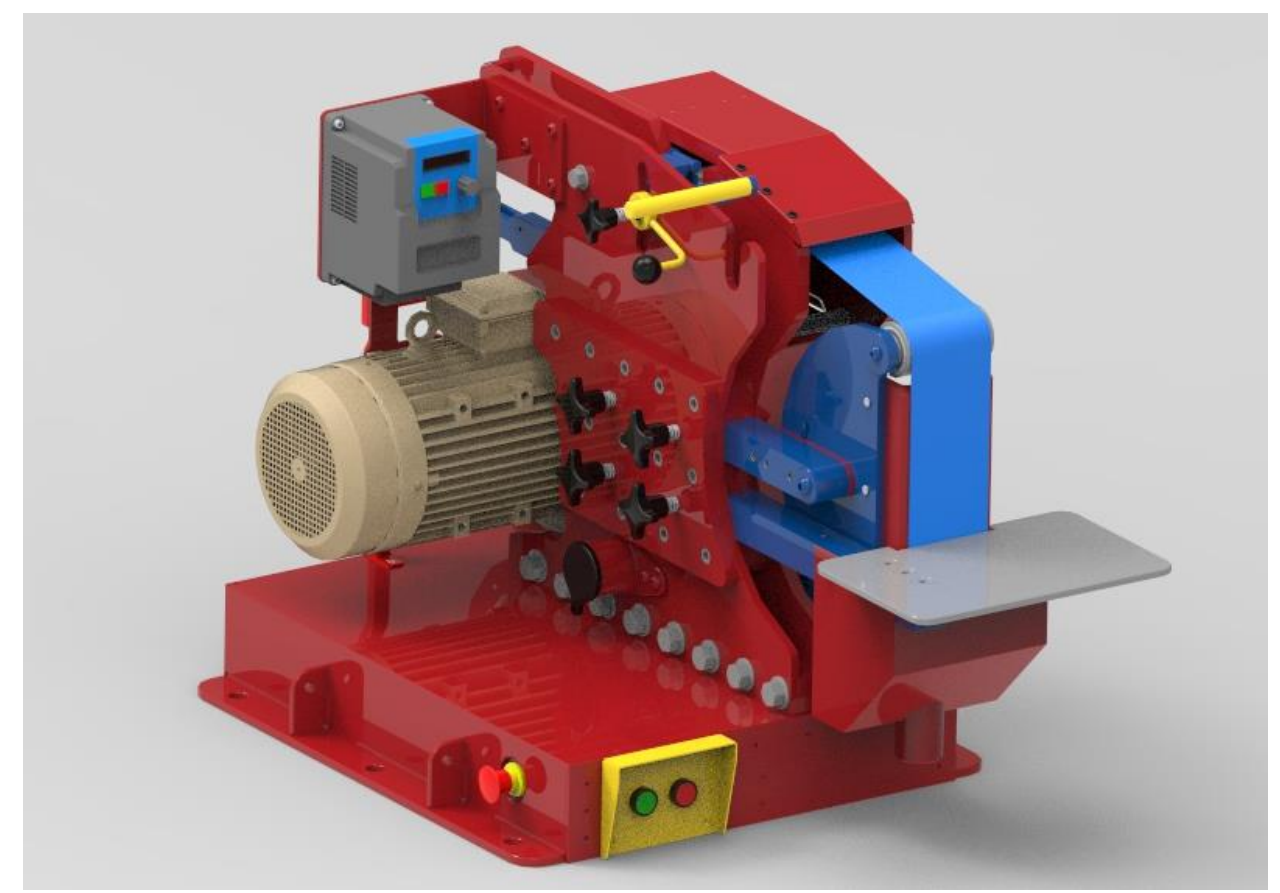

1. ábra: Szalagcsiszoló ST9 környezetben

A hajtás egy Agisys MST 100L1 B5 peremes 3kW-os háromfázisú aszinkron motor biztosítja, melynek alap fordulatszáma $2880 \mathrm{1} / \mathrm{min}$. A fordulatszám változtathatósága érdekében beépítésre 
került egy MOTOVARIO LM16 $340 \quad 0400$ F 20 típusú frekvenciaváltó. A fordulatszám változtatásával beállítható a megfelelő szalagsebesség és így különböző anyagokhoz különbözö forgácsolási sebesség állitható be a legjobb felületi minőség elérése érdekében.

\section{A szerkezet végeselemes analízise}

A végeselemes analízis az Ansys program 13.0 verziójával készült. Annak érdekében, hogy a hálózás során minél kevesebb csomópont legyen, a gépről a nem teherviselő alkatrészek nagy része eltávolításra került (2. ábra). Erre a müveletre azért van szükség, hogy a program minél hamarabb és minél nagyobb biztossággal lefusson. Az alkatrészek leszerelésével „csak” 1.520 .936 csomópont és 718.431 elem lett.
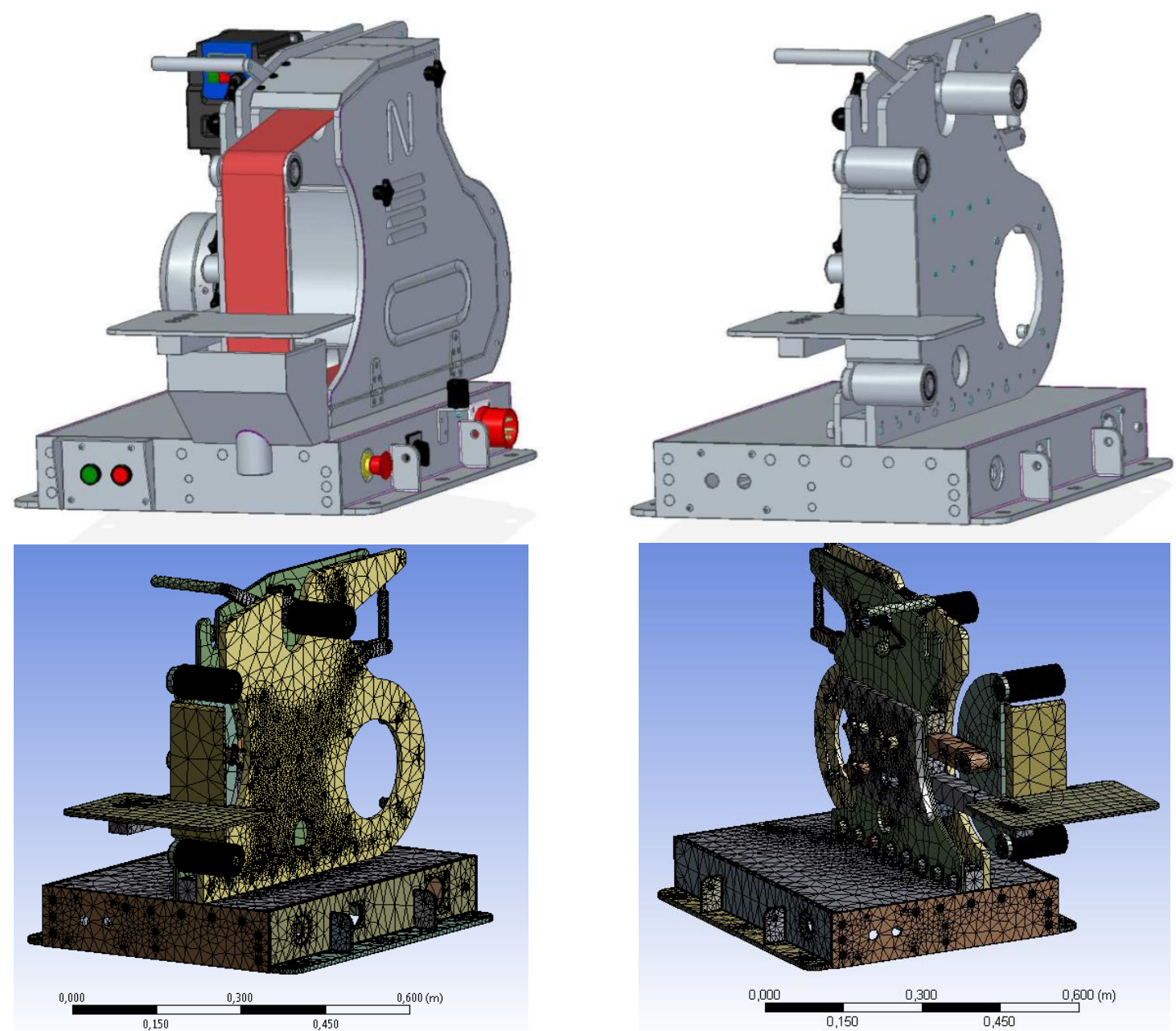

2. ábra: Fent: A szalagcsiszoló eredeti modellje és annak a VEM vizsgálatra elökészitett változata Lent: A modell hálózott képe 
A peremfeltételek megadásánál az első lépés a befogási pontok meghatározása: a talpfelületek kerültek lerögzítésre. Utána a különböző nagyságú erők elhelyezésére került sor a szerkezet különbözö pontjain: erőkkel lett ellátva a tárgyasztaltartó, a feszítő görgő és a két fordítógörgő is. A tárgyasztalt terhelő erők azt szimulálják, ahogy a felhasználó teljes erejével az asztal szélére támaszkodik, ez természetesen nem rendeltetésszerü használatot jelent. A 3. ábra mutatja a görgők terhelését és terhelési irányát.

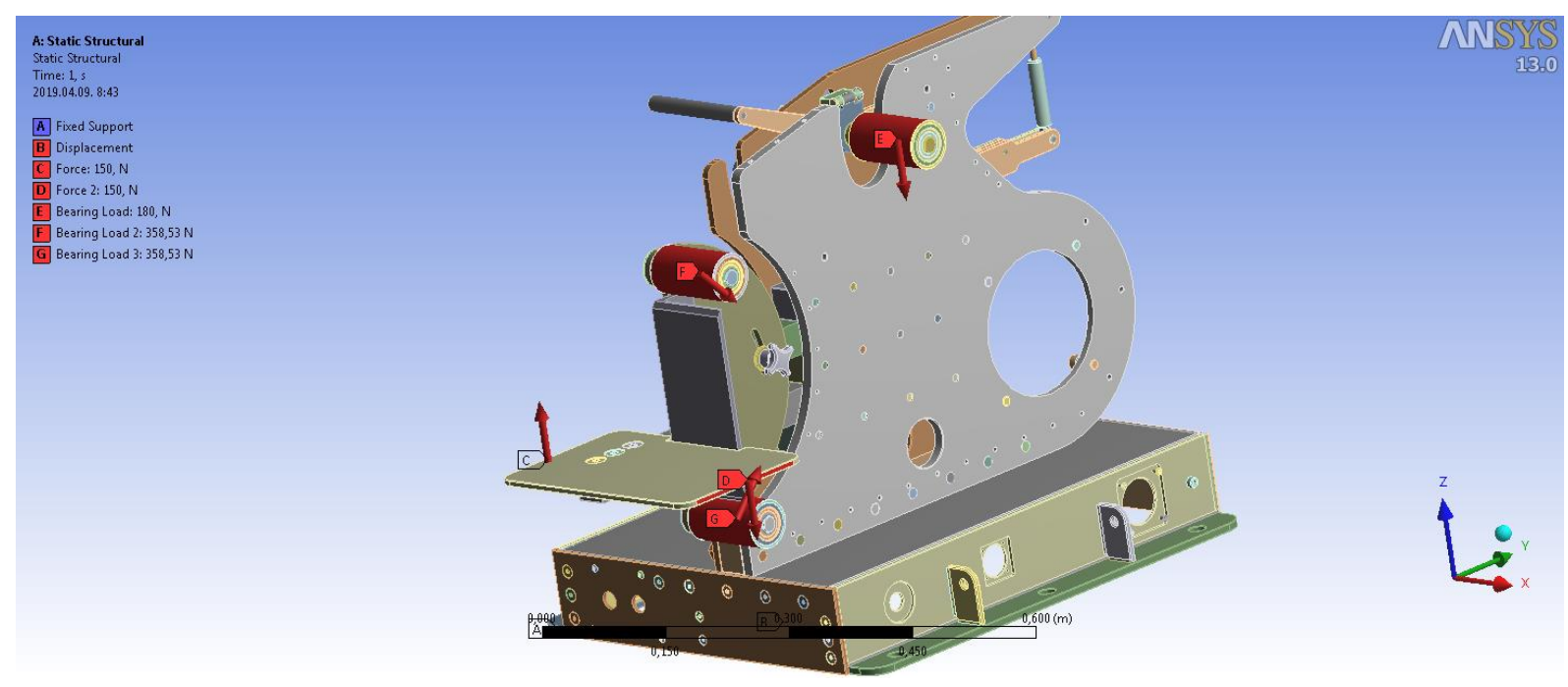

3. ábra: A szerkezet peremfeltételei

A program legalább 5 órán keresztül futott, végül megadta az eredményeket, melyeket a 4 . ábra és az 5. ábra szemléltet.

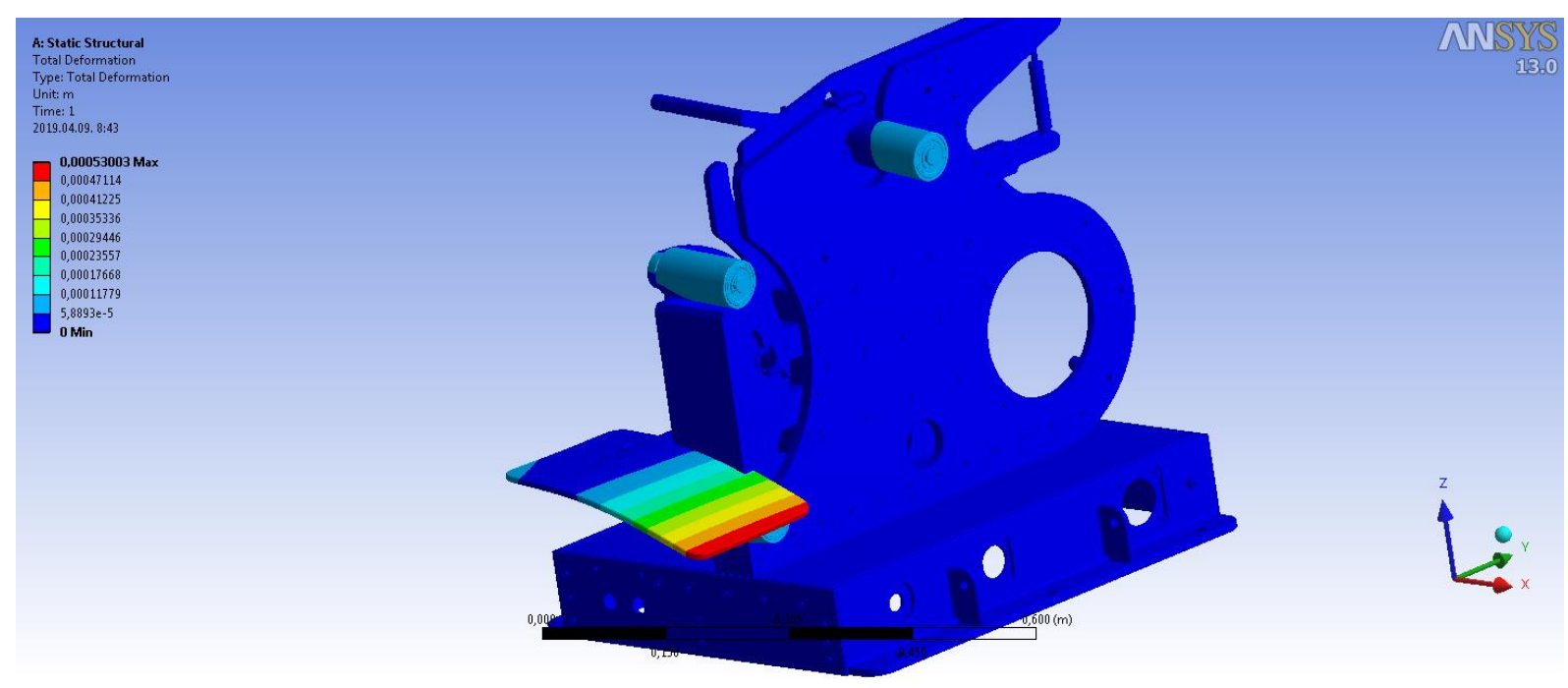

4. ábra: A szerkezet elmozdulása 
A nem rendeltetésszerü használatra való méretezés miatt a tárgyasztalon található a legnagyobb deformáció. A 5. ábra megmutatja, hogy a tárgyasztal összesen csak 0,53mm hajlik le „-Z” irányban. A legnagyobb feszültség szintén ezen az ábrán látható: a maximális feszültség az alsó fordítógörgö tövében ébred. Az értékek szerint a szerkezet statikailag megfelel. Néhány elem azonban túlméretezett, így a későbbiek során ezek optimalizálására még időt kell fordítani, amelyre több példát találunk a [6] irodalomban.

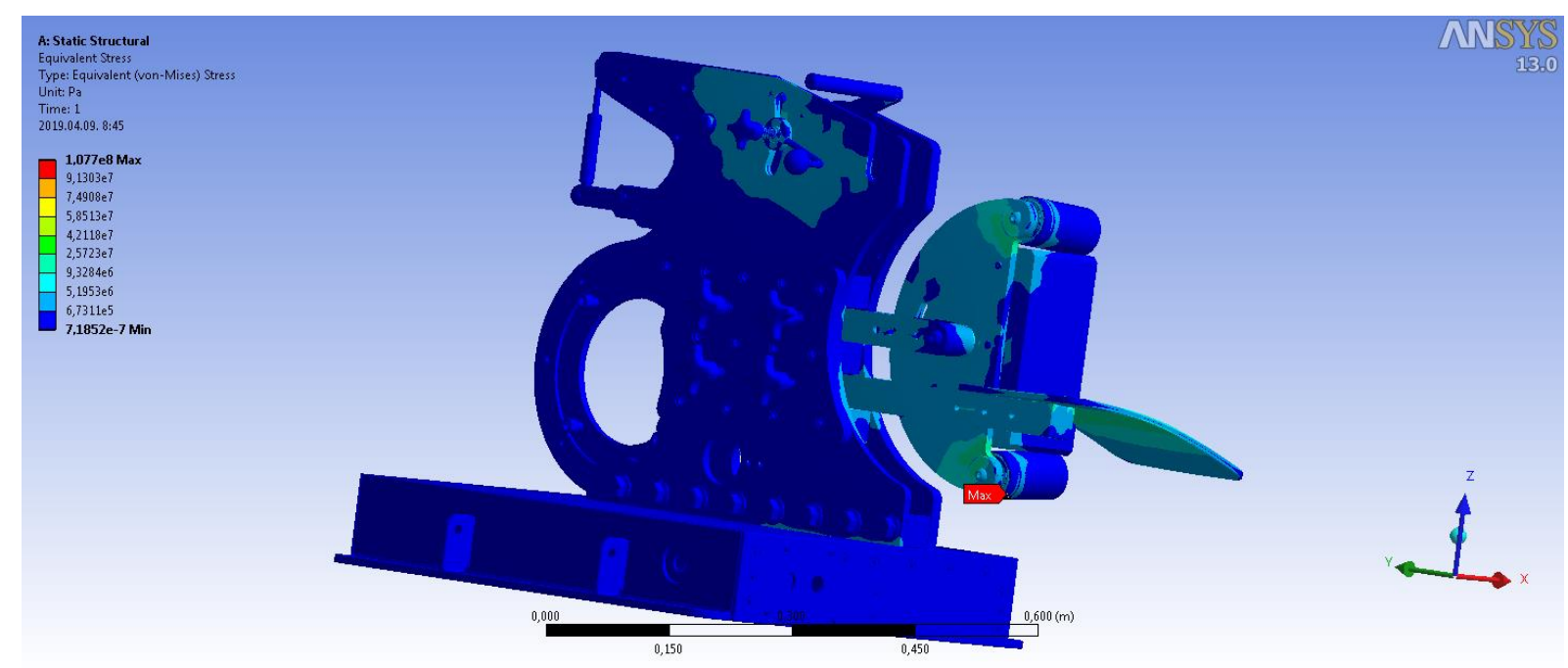

5. ábra: Feszültségek bemutatása

\section{4. Összefoglalás}

A koncepcionális tervezés során a szabadalomkutatás után feltárt funkciókból különféle megoldásváltozatok kerültek megfogalmazásra. A változatok értékelésével kiválasztásra került a szempontoknak leginkább megfelelő megoldás. A további tervezési feladatok ez alapján lettek kidolgozva. A számítások elvégzése $[1,2,4,5]$ és a szabadkézi vázlatok elkészítése után Solid Edge ST9 program segítségével készült el a gép 3D-s modellje [3]. A modellt végül végeselemes analízisnek alávetve, adódtak a deformációk és a feszültségek értékei. A konstrukció egy jól fejleszthető szerkezet, melynek értéke, sokoldalúsága kiegészítőkkel tovább növelhető.

Az elvégzett tervezési munka során egy alap szalagcsiszoló gép került kidolgozásra. Cél, ennek az alapkészüléknek a több-funkcióssá tétele a későbbiek során. Ezzel kapcsolatban az elkövetkezendőkben különböző kiegészítőket kell tervezni a géphez, mint például csőpalást-csiszoló adapter, csiszoló dob és cserélhető görgős csőhomlok csiszoló. A csőhomlok csiszoló alkalmas lesz két cső pontos összeillesztésére akkor, ha az egyik csövet homlokfelületével szeretnénk hozzá illeszteni egy másik cső palástfelületéhez. A gép alá még egy állványt is kell tervezni. Az állvány szekrény felépítésű lesz, így ez lehetőséget nyújt majd arra, hogy a gép tartozékait, kiegészítőit a felhasználó megfelelően és összeszedetten tárolhassa.

A továbbiakban mérések elvégzésével a motor pontos teljesítményszükségletét is meg kell állapítani, különböző kézi előtolási erőknél és változatos anyagminőségeknél. A teljesítménymérés mellet a 
csiszolószalagok szakítóvizsgálatával szükséges még foglalkozni, mind új és mind kopott, használt szalagok tekintetében.

\section{Köszönetnyilvánítás}

A cikkben ismertetett kutató munka az EFOP-3.6.1-16-2016-00011 jelü „Fiatalodó és Megújuló Egyetem - Innovatív Tudásváros - a Miskolci Egyetem intelligens szakosodást szolgáló intézményi fejlesztése" projekt részeként - a Széchenyi 2020 keretében - az Európai Unió támogatásával, az Európai Szociális Alap társfinanszírozásával valósul meg.

\section{Irodalom}

[1] Zsáry, Á.: Gépelemek I., Nemzeti Tankönyvkiadó, Budapest, 1989, ISBN: 9631945855

[2] Zsáry, Á.: Gépelemek II., Nemzeti Tankönyvkiadó, Budapest, 1991, ISBN: 963186443 X

[3] Herczeg, I.: Szerkesztési atlasz, Müszaki Könyvkiadó, Budapest, 1976, ISBN: 9631007901

[4] Fenyvessy, T., Fuchs, R., Gürtler, M., Csné., Plósz, A.: Müszaki táblázatok, , TCS Media Kft., Budapest, 2015, ISBN: 9789631222173

[5] Péter, J.: A géptervezés alapjai, Miskolci Egyetemi Kiadó, 2017, ISBN:978 9636618377

[8] Szabó, F. J.: Optimization possibilities and methods in product development and qualification, Design of Machines and Structures, 1 Vol 2, 2012. ISSN: 1785-6892

[6] Takács, Á.: Computer Aided Concept Building, Solid State Phenomena 261, 2017, pp.402-407, https://doi.org/10.4028/www.scientific.net/SSP.261.402

[7] Takács, Á., Kamondi, L.: On Design Theories: Fundamentals of a Neuvel Approach, Advanced Engineering 5 Vol.1, 2011, pp. 109-118. 